Man and Nature

L'homme et la nature

\title{
'Allusion' in the Eighteenth Century: The Disinherited Critic
}

\section{William Kinsley}

Volume 3, 1984

URI : https://id.erudit.org/iderudit/1011823ar

DOI : https://doi.org/10.7202/1011823ar

Aller au sommaire du numéro

Éditeur(s)

Canadian Society for Eighteenth-Century Studies / Société canadienne d'étude du dix-huitième siècle

ISSN

0824-3298 (imprimé)

1927-8810 (numérique)

Découvrir la revue

Citer cet article

Kinsley, W. (1984). 'Allusion' in the Eighteenth Century: The Disinherited Critic. Man and Nature / L'homme et la nature, 3, 23-45.

https://doi.org/10.7202/1011823ar

Copyright (C Canadian Society for Eighteenth-Century Studies / Sociéte canadienne d'étude du dix-huitième siècle, 1984
Ce document est protégé par la loi sur le droit d'auteur. L'utilisation des services d'Érudit (y compris la reproduction) est assujettie à sa politique d'utilisation que vous pouvez consulter en ligne.

https://apropos.erudit.org/fr/usagers/politique-dutilisation/ 


\section{2. 'Allusion' in the Eighteenth Century: The Disinherited Critic}

It is a truth almost universally acknowledged in the twentieth century that literary allusion is one of the most characteristic and most expressive techniques of English literature in the eighteenth century, and we seem to have taken it for granted that a more or less explicit theory lay behind eighteenth-century practice. On examination, though, it turns out that eighteenth-century writers actually said very little about the function of allusion and that, faced with this disinheritance, we have had to attribute to them a theory based almost entirely on inferences from their practice. In this paper I should like to examine the little that the eighteenth century did say about allusion, suggest some possible reasons for what seems to be a great disproportion between theory and practice, and decide whether, as a result, we should revise our understanding of allusive practice during the period.

My subject is 'literary allusion,' that is, the technique whereby a writer composes his text so that it echoes and brings to the reader's awareness an earlier text which significantly affects the meaning of the later text. Among the many varieties of terminology that have been proposed for the two texts, I prefer to call the later one the alluding text and the earlier one the target text. One of the advantages of this latter term is that it implies activity and intention on the part of the author and thus helps to 
distinguish allusion from passive submission to external influence. The author aims the reader's attention at the target text.

'Literary allusion' can be a misleading term, though, because it may suggest an opposition to musical or cinematic allusion, for example, whereas these are actually closely analogous to literary allusion. Just as one literary text can allude to another, so musical compositions can allude to other musical compositions, films to other films. A given form can also allude to a neighboring form: conversation to literary works, a film to a painting. A more general definition of this kind of allusion might therefore read somewhat as follows: a technique whereby any system of signs ('text' in a broad sense) is made to recall a previously existing system of signs in such a way as to significantly affect its own meaning. The fundamental opposition is between this kind of allusion and the whole range of topical and historical allusions that can be grouped together, for want of a livelier term, as 'ordinary allusions' that is, indirect or passing references to familiar objects, events, or persons in the real world - modern politicians, ancient generals, beautiful or otherwise notorious people, battles, strikes, scandals, etc. In this kind of allusion, sign systems refer to the real world, more or less directly; in 'literary' allusion there is also a reference to another sign system.

A brief example from Dryden's Mac Flecknoe can clarify this distinction. The second couplet of the poem reads

This Fleckno found, who, like Augustus, young

Was call'd to Empire, and had govern'd long:

A bit later, Fleckno declares

Even I, a dunce of more renown than they,

Was sent before but to prepare thy way;

And coursly clad in Norwich Drugget came

To teach the Nations in thy greater name.

In the first passage, Augustus is named directly, and Dryden expects his readers to know the facts about him that are relevant for the poem: his restoration of peace after civil war, his building programme that found Rome brick and left it marble, his patronage of outstanding poets like Horace and Virgil, and (just possibly) the despotic aspects of his rule. ${ }^{1}$ The second passage reminds us first of similar phrases in certain biblical texts (especially Matthew 3:1-4 and 11:7-10); these phrases describe John the Baptist and thus bring him into the poem. This second method offers more scope to the reader's activity - Augustus is given to him, but he 
has to go looking for John the Baptist, even if not very far. These two kinds of allusion are clearly very different, but the use of the same term for both of them has caused considerable theoretical confusion, and it is only quite recently, especially in the work of Ziva Ben-Porat and Carmela Perri, of 1976 and 1978 respectively, that this basic distinction has begun to be explored..$^{2}$ Since my primary concern here is literary allusion, I will not consider, for example, the way Opposition writers alluded to Sir Robert Walpole and his alleged wrongdoings, whether by nicknames like 'brazen-face' and 'Screen-Master General' or by recounting episodes from ancient history that were very similar to episodes in his career and then blandly denying the possibility of any contemporary application. ${ }^{3}$

A certain degree of similarity between the alluding text and the target text is obviously necessary for a successful literary allusion, but a certain degree of difference is equally necessary - a difference of genre, subject, tone, or the like. Otherwise the later text would not have enough independent meaning for the earlier text to act upon, but would simply repeat in its own context the meaning of the earlier text. Creating and interpreting allusions requires both wit and judgment in Locke's sense; one needs to be able to see both similarities and differences. ${ }^{4}$ From this situation arises the frequent comparison of the two texts of an allusion to the two terms of a metaphor, where both similarity and difference are also essential. ${ }^{5}$ (It is worth reminding ourselves here that, however similar the two texts may be, there is no allusion unless the meaning of the later text is affected.)

The interplay between similarity and difference is obvious enough in mock-heroic allusions, but it operates in other kinds as well. Consider the second line of Pope's couplet:

Laugh where we must, be candid where we can;

But vindicate the ways of God to Man. ${ }^{\circ}$

The echo of Milton's statement of purpose in Paradise Lost, 'And justify the ways of God to men,' is perfectly clear, not only in the phrasing but in the position of each line as the conclusion of the opening paragraph of a long poem. If Pope's line occurred in a blank verse poem about the fall of men and angels, it would have little allusive force because the author would be trying, and probably failing, to do about the same thing as Milton. If it occurred in a twentieth-century prose treatise on the problem of evil, it would have little allusive force because the contexts would be too different. Here, the differences balance the similarities. Milton's line does not rhyme with the preceding line, whereas Pope's 
does. Milton's line begins with 'And' and follows a statement of another equally solemn purpose: 'That ... I may assert Eternal Providence,' whereas Pope's begins with 'But' and follows a statement of a much less solemn purpose. 'Vindicate' is close in meaning to 'justify,' but not identical. Thus Pope's line both expresses his own purpose directly and implies, indirectly, that this purpose has something but not everything in common with Milton's, in both form and content.

These distinctions are not very rigorous, and are not at all exhaustive, but they will serve as a general description of the idea that has implicitly informed much of our study of eighteenth-century literature during recent decades. Among many other contributions we may note Earl Miner's book on Dryden, Reuben Brower's on Pope, and Christopher Ricks' essay on both poets. ${ }^{7}$ In view of my own bias toward theory, I should perhaps acknowledge that lack of an adequately explicit theory of literary allusion has not prevented these critics, and many others, from discussing it with great insight. They clearly know what it is.

As I have said, there is nearly universal agreement about the importance of literary allusion in our century. Particular interpretations may arouse two chief types of question: How much of his target text can a writer justifiably expect to allude to? What kinds and quantities of potential target texts can eighteenth-century writers and readers be expected to know? The late Earl Wasserman caused a number of raised eyebrows, and very few critics seem willing to extend the contexts of allusion as far as Wolfgang Rudat does. ${ }^{8}$ More recently, some critics have been treating the much broader phenomenon of intertextuality in such a way that allusion as a distinctive technique virtually disappears, ${ }^{9}$ but the most sustained critique of the role of allusion in the period comes from Irvin Ehrenpreis. ${ }^{10}$ This critique is only one part of a discussion of the place of implicit meaning in Augustan literature and therefore makes no claim to be exhaustive, but as usual when he attacks conventional wisdom about the eighteenth century Ehrenpreis teaches us something even if we finally decide to maintain the convention.

Ehrenpreis finds two main weaknesses in most allusion critics: first, if there is more than one possible source for an allusion, they arbitrarily pick the most prestigious - Milton rather than Blackmore, Virgil rather than Boileau, Horace rather than a minor poet from the Greek Anthology; second, they seriously overestimate the erudition of the average eighteenth-century reader. Both arguments seem to me to call attention to important aspects of eighteenth-century allusion but to view them 
from the wrong perspective. In his first argument, Ehrenpreis has perhaps been victimized by his own erudition, and he fails to distinguish between allusion and passing imitation. If we can point to three or four possible sources for a passage, he asks, why should one be singled out as the focus of an 'allusion'? He seems to imply that the multiplicity of possible sources makes them all equally accidental, that if a text echoes six different earlier texts it cannot really allude to any of them. The rebuttal seems fairly obvious - in most cases, only the prestigious ancient is different enough from the modern to allow room for the allusion to operate. Also, since one of the most important functions of eighteenth-century allusion is to enable the author to make implicit moral judgments, prestige is an important aspect of the target text. On a more practical level, the best-known author is clearly the best target for an allusion more readers know Horace than the minor Greeks. More fundamentally, allusion is not merely a matter of resemblance to an earlier text but of effect on the meaning of a later text; some resemblances are allusions and some aren't, just as some sound patterns reinforce meaning and some don't. When faced with a number of possible sources, it is not arbitrary but essential to center on the one or two that are important for the meaning of the later text. To be sure, Ehrenpreis does catch some critics taking their own wish for an allusion for the poet's deed, or using doubtful allusions to support dubious readings of a poem, but it doesn't seem to me that this argument lessens in principle the importance of allusion.

In the second argument, which is perhaps not quite consistent with the first, Ehrenpreis turns from the multiplicity of possible allusions to the eighteenth-century reader's limited ability to recognize any of them. The main support for his contention that Sir John couldn't read very well either is the footnotes that several writers appended to their poems. ${ }^{11}$ If, for example, at Canto IV, line 1 of The Rape of the Lock, Pope felt obliged to footnote his allusion to Book IV, line 1 of the Aeneid, 'by far the best-known part of the best-known of all [classical] poems,' what are we to think of the level of literacy of his readers (p. 13)? At first glance this doubt seems more reasonable than Wasserman's confidence (pp. 27-28) that such notes are meant to stimulate the reader to search out unannotated echoes. When Ehrenpreis goes on to say that 'Dryden's notes to Annus Mirabilis have equally cruel implications,' though, he is on less firm ground. Here is how Dryden introduces these notes: 'In some places, where either the fancy, or the words, were his [Virgil's], or any others, I have noted it in the Margin, that I might not seem a Plagiary.'12 Far from presuming to tell his readers anything they don't know, Dryden is covering himself by proclaiming his own awareness of those imitations that he believes his readers are likely to spot. ${ }^{13}$ Like other writers we shall soon 
examine, Dryden is not concerned at all with allusion in our sense, but only with imitation. Another very heavily annotated work of this period is The Pilgrim's Progress, whose margins are sometimes solidly black with citations to the Bible. Bunyan's motive seems to have been to proclaim his scriptural orthodoxy and authenticity, to defend his use of fiction by showing that it rested on biblical fact; certainly no one would conclude from the presence of these notes that his readers didn't know their Bible! Pope's announcement of his notes to the Dunciad is probably more a part of his satire of his readers than a reliable indication of the real state of their literacy: The Imitations of the Ancients are added, to gratify those who either never read, or may have forgotten them; together with some of the Parodies, and Allusions to the most excellent of the Moderns. ${ }^{\prime 4}$ Pope's note to The Rape of the Lock IV.1 does seem embarrassing; yet we should recall that he tried to accommodate his female readers, very few of whom knew Latin and most of whom had probably not read Dryden's translation. In any case, the import of footnotes is much more complicated than Ehrenpreis grants, and I at least am unwilling to allow them to diminish the importance of allusion for eighteenth-century literature.

As we turn now to examine what eighteenth-century writers thought about allusion, we immediately face serious terminological problems. 'Allusion' was an extremely vague term in the eighteenth century. Besides its present meaning, it could also signify figure, pun, comparison, trope, metaphor, reference in a very broad sense, or merely imitation. ${ }^{15}$ Unless the context provides a clue, there is seldom any way of telling whether the word carries anything like its modern sense or not. In Pope's statement quoted above, for example, there is no clear distinction between imitations, parodies, and allusions. A few more examples will deepen our awareness of the range and ambiguity of our term:

The Great Art of a Writer shews it self in the Choice of pleasing Allusions, which are generally to be taken from the great or beautiful Works of Art or Nature; for though whatever is New or Uncommon is apt to delight the Imagination, the chief Design of an Allusion being to illustrate and explain the Passages of an Author, it should be always borrowed from what is more known and common, than the Passages which are to be explained.

Allegories, when well chosen, are like so many Tracks of Light in a Discourse, that make every thing about them clear and beautiful. A noble Metaphor, when it is placed to an Advantage, casts a kind of glory round it, and darts a Lustre 
through a whole Sentence: These different Kinds of Allusion are but so many different Manners of Similitude ...

Thus Addison in Spectator 421, part of the series on the pleasures of the imagination. ${ }^{16}$ In the original printing of No. 205, Addison signaled the transition from a description of a vicious character as a scarecrow to a warning against 'the Shoals and Quicksands of Life' by writing To change the Metaphor.' For the reprint, 'Metaphor' was changed to 'Allusion,' with little discernible change in meaning (2.302). With no less confusion, Defoe, an author seldom included in discussions of allusion, calls Robinson Crusoe an 'allusive allegorick History. ${ }^{17}$ Richard Hurd writes of the folly of taking resemblances for imitations, in this province of allusion. ${ }^{18}$ Bolingbroke associates allusion with other outmoded kinds of discourse, as contrasted to the demands of the present for reason and fact: Men now require something more real than figure, more precise than allusion, and more particular than metaphysical abstractions. ${ }^{19}$ Johnson's well-known discussion of metaphysical imagery maintains the uncertainty: 'The most heterogeneous ideas are yoked by violence together; nature and art are ransacked for illustrations, comparisons, and allusions. ${ }^{20}$ Johnson also testifies, in a kind of pre-incarnation of Ehrenpreis, that the eighteenth century, like the twentieth, had its allusion-hunters: critics with telescopes

see with great clearness whatever is too remote to be discovered by the rest of mankind, but are totally blind to all that lies immediately before them. They discover in every passage some secret meaning, some remote allusion, some artful allegory, or some occult imitation which no other reader ever suspected..$^{21}$

Since we don't know what kind of allusion Johnson has in mind here, his evidence cannot contribute to our present investigation.

Comments on particular poems may be a little clearer than these general statements. In a note to Dunciad 3.53, Pope says This has a resemblance to that passage in Milton, 'from which he quotes three lines before continuing 'there is a general allusion in what follows to that whole passage' (TE, 5, 155). This seems promising, but we cannot be sure exactly what force the term had for Pope, and he offers no hint of what he sees as the significance of his allusion. Nor, again, does Richard Hurd: Learned writers of quick parts abound in these delicate allusions. It makes a principal part of modern elegancy to glance in this oblique manner at well-known passages in the classics' (Works, 2, 308). Even more mysterious is James Beattie. In Book I, stanza 44 of The Ministrel he refers to a 'long-winded tale' featuring hags, that suckle an infernal 
brood, / And ply in caves th'unutterable trade.' An asterisk directs us to the bottom of the page, where we read 'Allusion to Shakespear. Macbeth. How now, ye secret, black, and midnight hags, What is't you do? Witches. A deed without a name. Macbeth. Act 4. Scene 1.'22 Nowhere else in the poem does Beattie provide a signpost to an allusion, and in spite of great effort I've been unable to discover why he does so here.

Unless I've missed something essential, then, it seems clear that assembling examples of 'allusion' will not help us greatly to discover what the eighteenth century thought about the subject. We will explore some other avenues in a moment, but none of them will lead to anything like a comprehensive theory. It is puzzling, this contrast between the pervasiveness of the practice of allusion (unless we moderns have indeed greatly overestimated its importance) and the paucity of explicit discussion of it. Eighteenth-century critics certainly had at hand everything they needed to work out a theory. Apart from Pope's practice, there was Dryden's highly concentrated use of allusion in Mac Flecknoe and Absalom and Achitophel, not to mention many other less popular works. Before him, there was Milton. There was classical sanction in Virgil's use of Homer. There were well codified methods of reading the Bible typologically, rather weakened from their patristic and medieval origins, but still influential in some quarters. ${ }^{23}$ Associationist psychology was ready with a convenient conceptual framework for explaining the operation of allusion. Yet David Hartley devotes a long chapter of his Observations on Man to 'Associations of Words' without coming close to allusion. Hartley was not particularly interested in literature, of course, but Alexander Gerard was in his Essay on Genius (London, 1774). He devotes several chapters to the various kinds and effects of the association of ideas, and he states that a single word can remind a reader of a large context, but he is interested only in memory, not in allusion:

When memory presents one event, this leads us to think of the other events which were connected with it, and to conceive them in their proper order. The remembrance of many periods of a discourse or of a great number of verses, is often revived by the single word with which they begin. (p. 252)

Hugh Blair, Adam Smith, Lord Kames, Lord Monboddo are equally silent as far as I have been able to discover.

Another way into our subject that looks promising is via 'parody.' We have seen the term in Pope's preface, and will see below how Warton uses it in his Essay on Pope. Johnson's definition, in his dictionary, is useful: 'A kind of writing, in which the words of an author or his 
thoughts are taken, and by a slight change adapted to some new purpose.' This definition accounts for the difference between the two texts that is essential for allusion, and it avoids limiting the meaning of parody to ridicule of the text parodied, in striking contrast, for example, to the OED. Such a definition could provide a good starting point for a theory of allusion, but Johnson provides only one illustrative quotation: Pope's statement about the Dunciad notes in which, as we have seen, parody, allusion, and imitation are not clearly distinguished. Elsewhere, though, Johnson clearly shows his awareness of one way allusion can operate. In the well-known Rambler 168 he condemns the unsuitably low diction of a passage in Macbeth: 'dun' is a word used by stable hands, knives belong to a menial occupation, and, in general, 'words become low by the occasions to which they are applied, or the general character of them who use them; and the disgust which they produce, arises from the revival of those images with which they are commonly united.' He goes on to treat literary allusion, though without naming it, as a special case of the influence of past associations on the effect of words:

Thus if, in the most serious discourse, a phrase happens to occur which has before been successfully employed in some ludicrous narrative, the most grave and serious auditor finds it difficult to refrain from laughter, when those whose imagination is not prepossessed by the same accidental association of ideas, are utterly unable to guess the reason of his merriment. (Works, 5, 126-27; quoted in the folio version, which is a bit more explicit.)

What makes this a real discussion of literary allusion is the focus on the meaning of the alluding text. Allusion from a serious text to a ludicrous one is less common in the eighteenth century than is allusion in the other direction, and when it does occur it is usually unintentional, but the operation is the same. Johnson's analysis also testifies to the importance of the association of ideas as a basis for allusion. Being primarily concerned with diction, though, he didn't carry his discussion of allusion any farther.

The Jonathan Richardsons, father and son, help a little and tantalize a great deal in their Explanatory Notes and Remarks on Milton's Paradise Lost (1734). Commenting on 4.778, where the cherubim leave heaven through an 'Ivory Port,' they remind us of Homer's two gates of sleep, of horn and ivory, through which respectively issue true and false dreams, and to which Virgil is thought to have alluded in Aeneid VI in order to imply that Aeneas's visit to the underworld is a poetical fiction. They argue that if Milton intended to allude to these predecessors, his purpose, like Virgil's, was to underline the fictiveness of his descriptions. They 
conclude by admitting that 'this is only Offer'd as a Conjecture; but most Certain it is He could not Forget this Ivory Gate of Homer, whether he Alluded to it or No' (pp. 178-79). This is the only place where the Richardsons treat an allusion as such, though, and the status of the gates of horn and ivory as famous symbols almost independent of their original texts perhaps lessens the value of their observation for our purposes. Richardson Sr. tantalizes us in his preface:

My Son has a very Copious Collection of [Milton's imitations], and as they often Assisted Us in Our Understanding Our author's true Meaning, they would (if inserted) have been Our Vouchers in Those Cases. To have added All These Fine Passages would have been Improper in Our Present Undertaking ... . (pp. cli-clii)

We cannot be sure how they would have related their copious collection to Milton's meaning, but we can wish that they had at least given us a few samples. We might expect help from Gilbert Wakefield's Observations on Pope (1796) because of his keen ear for echoes, but he doesn't point out the allusive significance of the sources he discovers. His preface seems to disclaim any such intention: 'My sole aim and desire has been to illustrate Pope, as an elegant English classic, by opening the sources of his imitation, by noticing his beauties of sentiment and expression, and occasionally his improprieties in both' (p. xvi).

Joseph Warton's Essay on the Genius and Writings of Pope adds a little material to our discussion. ${ }^{24} \mathrm{~A}$ propos of The Rape of the Lock, he observes

The parodies are some of the most exquisite parts of this poem. That which follows from the 'Dum juga montis aper,' of Virgil [i.e., 3.165ff.], contains some of the most artful strokes of satire, and the most poignant ridicule imaginable.... The introduction of frequent parodies on serious and solemn passages of Homer and Virgil, give much life and spirit to heroi-comic poetry. ... The mind of the reader is engaged by novelty, when it so unexpectedly finds a thought or object it had been accustomed to survey in another form, suddenly arrayed in a ridiculous garb. (1.243-45)

These expressions are satisfactory as an initial description of the general effects of Pope's allusions, but Warton doesn't try to show in detail how those effects are produced, and his attention seems focussed at least as much on the target text as on the alluding text. He discusses the Dunciad in a similar vein: 'The frequent parodies introduced on Homer, Virgil, Milton, and other great poets, than which nothing has a stronger effect in heroi-comic poems, are made with a singular pleasantry, happiness, and 
judgement' (2.378-79). When he turns to Pope's satirical use of the Bible, though, his entire attention is devoted to the effect of the parody on the target text, and he can only speak of 'profaneness' (2.380).

He comes closest to describing how allusion actually works in his comment on An Essay on Man I.16, which we examined above: 'Pope seems to have hinted, by this allusion to the Paradise Lost, that he intended his poem for a defence of providence, as well as Milton' (2.63). Even here, though, he concentrates on similarity to the neglect of difference. His succeeding comments show a clear awareness that Pope's purposes are different from Milton's, but he does not explicitly interpret the differences between the alluding text and the target text as signals of the difference of purpose.

Imitation is an essential aspect of allusion, and there is no shortage of eighteenth-century discussions of imitation. They turn out to be useful for us, however, less for what they have to say about allusion than for the way they steadily avoid the subject. Throughout this part of my essay I am greatly indebted to Roger Lonsdale's article, 'Gray and "Allusion": The Poet as Debtor. ${ }^{25} \mathrm{He}$ has covered imitation very thoroughly, and any suspicions that I suffer from the anxiety of scholarly influence are justified. Throughout classical antiquity, the Middle Ages, and the Renaissance, imitation was regarded as a normal and necessary part of literary composition. ${ }^{26}$ Only piracy - claiming another writer's work as one's own - and the most servile kind of close copying were generally condemned. The bee that gathers nectar from many sources - best known to us from its starring role in Swift's Battle of the Books - has a long and honourable history as an emblem of creative imitation. ${ }^{27}$

Imitation retained its place of honour in eighteenth-century theory. In his Preface of 1717 Pope declares that 'all that is left us is to recommend our productions by the imitation of the Ancients' (TE, 1, 7). A more remarkable discussion of imitation, one of the few relevant texts not mentioned by Lonsdale, occurs in Guardian 12:

But over and above a just Painting of Nature, a learned Reader will find a new Beauty superadded in a happy Imitation of some famous Ancient, as it revives in his Mind the Pleasure he took in his first reading such an Author. Such Copyings as these give that kind of double Delight which we perceive when we look upon the Children of a beautiful Couple; where the Eye is not more charm'd with the Symmetry of the Parts, than the Mind by observing the Resemblance transmitted from Parents to their Offspring, and the mingled Features of the Father and the Mother. ${ }^{28}$

Here the earlier text, as an object of imitation, has a status virtually 
equivalent to that of Nature as Addison sees it in The Pleasures of the Imagination':

This Secondary Pleasure of the Imagination proceeds from that Action of the Mind, which compares the Ideas arising from the Original Objects, with the Ideas we receive from the Statue, Picture, Description, or Sound that represents them. (Spectator 416; ed. Bond, 3, 559-60)

In contrast to most imitations, recognition of the ancient text is necessary here in order to achieve the double significance or 'new beauty' which is based on the relationship between the two texts. We also have a striking use of the metaphor of transmission and inheritance that Miner and Ricks have shown to be so fundamental in the poetics of Dryden and Pope (see note 7). It would seem to be only a step to a discussion of the impact of the earlier text on the meaning of the later one, but our author doesn't take that step. He does go on to state that allusions to the Bible or to ancient poets can add to the dignity of modern sermons or poems, but here, as in the passage quoted, he concentrates on similarity, on the way one text reproduces another.

Other Renaissance metaphors for imitation besides filiality and the bee recur in the eighteenth century. The earlier text is often figured as a mine or quarry from which the poet digs out materials, and one of a poet's merits is his ability to find material in unlikely places. Pope provides a satirical version of this image in the Peri Bathous: 'Virgil is said to have read Ennius, out of his Dunghil to draw Gold, so may our Author read Shakespear, Milton, and Dryden, for the contrary End, to bury their Gold in his own Dunghil.'29 The success of an imitation often depends on the relative poetic merits of the borrower and the lender. Here the complementary metaphors are theft and military conquest, with negative and positive connotations respectively. Dryden justifies Ben Jonson's numerous borrowings in this way, granting him a kind of droit $d u$ seigneur over all the poetry produced in his domain:

But Ben made nobly his, what he did mould,

What was another's Lead, becomes his Gold;

Like an unrighteous Conqueror he raigns,

Yet rules that well, which he unjustly gains. ${ }^{30}$

One implication of all these metaphors is identical: once the excavated, or quarried, or conquered material is in place in a new text, its origin ceases to have any relevance for its meaning except perhaps as a testimony to the author's apian industry. 
In spite of this theoretical sanction, however, as Lonsdale has shown so well, the practice of imitation produced great uneasiness in eighteenthcentury poets. We have seen Dryden's defensive remarks in his preface to Annus Mirabilis. The youthful Pope inquired of his friend Walsh how far the liberty of Borrowing may extend. ${ }^{31} \mathrm{He}$ was concerned about his pastorals, which are extremely imitative but not very allusive. He goes on to compare the borrowing writer to a branch grafted onto a tree of another stock so as to 'yield variety,' and then declares that 'a mutual commerce makes Poetry flourish; but then Poets like Merchants, shou'd repay with something of their own what they take from others; not like Pyrates, make prize of all they meet.' Wolfgang Rudat has made much of this passage as an emblem of Pope's allusive technique, but it is hard to see where the mutuality lies (see note 8). How does one repay Virgil for the lines one takes from him? By enshrining him in one's own poem as an act of homage? Perhaps, but the mercantile metaphor seems to me to intensify the air of doubt and uncertainty that the opening question reveals; again, there is no hint that the ancient text affects the meaning of the modern one. Later in his career Pope seems to have gone so far as to suppress a projected compilation of his imitations and parodies by William Bowyer. ${ }^{32}$

As the century progressed, this anxiety of imitation became more and more acute as more and more curious scholars investigated the borrowing habits of poets both ancient and modern. Critics worked hard to distinguish between real borrowings, coincidental resemblances, similarities determined by the nature of the subject, and other varieties of imitation and near imitation. Could vernacular poets be imitated as freely as the classics? Could contemporaries be imitated as freely as Elizabethans?

Two pervasive features of these discussions are important for our purposes: their forensic tone and the constant recurrence of competition and emulation as hallmarks of imitation. Pope himself provides an example of the latter in his definition of true wit as What oft was Thought, but ne'er so well Exprest' (Essay on Criticism, 298). It is prominent in the two dissertations that Richard Hurd published in 1751 as appendices to his edition of Horace: 'On Poetical Imitation' and 'On the Marks of Imitation.' Writers proclaim imitation, he says, 'when they have a mind to shew their dexterity in contending with a great original. ${ }^{\prime 33}$ Warton is more explicit in his Essay on Pope, whose pastorals, closely imitated from Virgil and Theocritus, are judged inferior to their models (1, 1-11). Messiah, though, 'incontestably surpasses the Pollio of Virgil' (11). At the beginning of his discussion of the Imitations of Horace, he mentions that Pope modified Horace's style by following that of Juvenal $(2,274)$, 
but thereafter nearly all his remarks are comparisons of the quality of corresponding passages in the two poets. In all such exercises he takes great care to be impartial:

As I before produced a passage of Milton which I thought superior to a similar one of Pope, I shall, in order to preserve impartiality, produce another from Milton, in which I think him inferior to the last quoted passage, except perhaps in the third line. $(1,26)$

Behind all these judgments lies the assumption that the imitator is trying to do the same thing as his model and that the only question is who does it better. Once the judgment is made, the losing text can almost be discarded. Edward Young distinguishes imitation from emulation, but he also takes it for granted that in both cases the later poet is doing the same thing as the earlier; the difference is that the imitator is content to do less well than his model, whereas the emulator tries to do better. ${ }^{34}$

Forensic language sets the tone of the introductory question of Hurd's first dissertation, and throughout he conducts himself like a prosecuting attorney: Whether, in the case of confessed Imitations, any certain and necessary conclusion holds to the disadvantage of the natural GENIUS of the imitator?' (p. 110). 'Coincidences of a certain kind, and in a certain degree, cannot fail to convict a writer of imitation' (p. 214). 'Every degree of likeness is exposed to the suspicion of imitation' (p. 252). 'An identity of phrase and diction, is a much surer note of plagiarism ... There is no defending coincidences of this kind' (p. 208; Hurd's italics throughout). Yet by the end of the dissertation, we realize that Hurd is really acting as defence attorney, not as prosecutor: he seldom accuses writers of plagiarism, but rather defends them against anticipated accusations from his readers. He concludes this part of his argument:

It follows, from these considerations, that we cannot justify ourselves in thinking so hardly, as we commonly do, of the class of imitators; which is, now, by the concurrence of various circumstances, become the necessary character of almost all poets. Nor let it be any concern to the true poet, that it is so. For imitations, when real and confessed, may still have their merit; nay, I presume to add, sometimes a greater merit, than the very originals on which they are formed'. (p. 229)

Yet by constantly assuring us that imitation is normal, natural, and indeed inevitable, he betrays in himself the same anxiety that he finds in his contemporaries: 
though many causes concur to produce a thorough degeneracy of taste in any country; yet the principal, ever, is THIS ANXIOUS DREAD OF IMITATION IN POLITE AND CULTIVATED WRITERS. (p. 240)

Warton is equally cautious, protesting, after a ten-page list of Pope's presumed borrowings from other writers,

I should be sensibly touched at the injurious imputation of so ungenerous, and indeed impotent a design, as that of attempting to diminish, or sully the reputation of so valuable a writer as Pope, by the most distant hint, or accusation of his being a plagiary. $(1,98)$

He goes on to defend Boileau against similar imputations. So with William Clark in his projected annotations of Pope: far from making accusations, or even treating his discoveries as texts deliberately alluded to, he writes to Bowyer

I hope you do not suppose that Mr. Pope had half those passages in his thoughts that bear a resemblance with them. Poets, like painters, in this respect, are furnished with a collection of figures, images, drawings, descriptions, \& c. which are always ready in their heads, without thinking of the original. ${ }^{35}$

Right in the middle of all these questions is Thomas Gray. Immensely learned, severely inhibited, obsessively imitative, he constitutes a crucial test-case for eighteenth-century allusiveness. Contemporary readers found scores of borrowings in his very small corpus, nineteenth-century editors added scores more, and Roger Londsdale's edition, another source of great indebtedness for me, lists literally hundreds in its massive footnotes. ${ }^{36}$ Gray was both praised and censured by his contemporaries for the way he borrowed from his predecessors, and in his collected Poems of 1768, in Lonsdale's words, he

felt obliged to acknowledge for the first time a number of his 'imitations,' all of them notably acceptable according to traditional theory, some even ostentatious in their obscurity: they include Homer, Virgil, Lucretius, Dante, Petrarch, Spenser, Shakespeare, Milton and even Dryden but, with one exception, no later poet. ${ }^{37}$

Like Dryden's notes to Annus Mirabilis, Gray's are designed more to forestall carping critics than to instruct ignorant ones, though the latter motive is certainly present in Gray as well. This is borne out by a comment in an earlier letter about accusations of plagiarism: 'I could shew 
them a hundred more instances, wch they never will discover themselves. ${ }^{38}$ Gray sounds almost like the bank robber who accepts a jail term cheerfully, knowing that his securely hidden loot will be waiting for him when his sentence expires. As Lonsdale tells us, though, most of his additions to the body of Gray's borrowings come from the main line of English poetry since Spenser (p. 31). Ancients, moderns, Englishmen, Europeans, the famous, the obscure - Gray imitated everyone, eclectically and enthusiastically.

Not the least striking aspect of all these imitations is how few of them are allusive. The keenest allusion hunters, furnished by Lonsdale with an apparatus which makes the California Dryden and the Twickenham Pope look under-annotated, have found very little game. Harold Bloom mentions in passing that Gray is second only to Milton for 'allusive density, 'but he must be using the term in a sense different from mine, and in any case he gives no examples and doesn't develop his pronouncement. ${ }^{39}$ Someone has tried to find allusive significance in the way 'the crested pride / Of the first Edward' (The Bard, 9-10) echoes 'the crested adder's pride' from a song in Dryden's Indian Queen, III, i, but I am not convinced. Importing the meaning of 'adder' into Gray's text, even if a legitimate method, doesn't add much to the bard's denunciation of Edward, and the rest of Dryden's song is too commonplace to provide any enrichment. Thomas Gilmore tries to apply Earl Wasserman's methods to the Eton College ode, but the results, compared with what one finds in Pope, strike me as meagre. ${ }^{40}$ Perhaps the reason is that allusion is too intellectual a method to communicate very well the delicate emotional tones evoked by this poem. The 'Ode on the Death of a Favorite Cat,' a much more Augustan performance with its sly humour and potential mockheroics, might seem to offer more scope for allusion. In his essay, Lonsdale examines the candidates, from Helen of Troy to Virgil's Camilla, that have been proposed as allusive avatars of Selima the cat, and I must agree with him as he adopts Ehrenpreis's skeptical stance and concludes that none of them is very central to Gray's poem (pp. 48-54). There is no lack of parallels, echoes, and resemblances, but their effect on the meaning of Gray's poem is negligible. One of Gray's few real allusions occurs in his brief but mordant satire, 'On Lord Holland's Seat near Margate,' where line 16, 'mimic desolation covers all,' aptly echoes the close of the Dunciad, 'Universal Darkness buries All.'41 The effect of the allusion is to associate Gray's little poem with Pope's much larger one, thereby implying that Lord Holland's estate is not an isolated aberration but part of a more general cultural collapse. Otherwise, it seems to me that the only allusive effect of Gray's many borrowings is a very generalized one, a kind of acknowledgment of his poetic predecessors 
and an implicit declaration that he is carrying on their tradition and is grateful for the materials they have supplied him with.

With one major exception: an emphatic, and very problematic, allusion that also involves the Dunciad. It is certainly unintentional, and it seriously damages his own text. In the third stanza of 'The Progress of Poesy,' Gray describes the infant Shakespeare ('thy' in the second line refers to England):

Far from the sun and summer-gale,

In thy green lap was Nature's darling laid,

What time, where lucid Avon strayed,

To him the mighty Mother did unveil

Her awful face:

These few lines contain loud echoes of three separate passages of the Dunciad, all of which refer to Dulness or to Colley Cibber. Their juxtaposition to Gray's lines shatters the mood of high sublimity that he was trying to maintain. ${ }^{42} \mathrm{He}$ has inadvertently made himself into a Dunce after the fact:

The Mighty Mother, and her Son who brings

The Smithfield Muses to the ear of Kings,

I sing.

A veil of fogs dilates her awful face. (1.262)

But in her Temple's last recess inclos'd,

On Dulness' lap th'Anointed head repos'd.

Him close she curtains round with Vapours blue,

And soft besprinkles with Cimmerian dew. (3.1-4)

Nor is this discovery the work of a mischievous modern allusionmonger. It was noted in the eighteenth century by a writer in The Gentleman's Magazine who 'regretted that the reader was so "forcibly reminded" of Pope,' and by Gilbert Wakefield, who remarked in his 1786 edition of Gray's poems that 'wicked memory brings into the mind the Queen of the Dunces, and destroys all the pleasure of the description by an unlucky contrast.' 43 The situation here is similar to the one described in general terms by Johnson: the memory of a ludicrous text destroys the effect of a solemn one. There is clearly nothing ludicrous about Gray's diction as such. The relation between allusion and intention has occupied many critics, and most would deny the possibility of unintentional allu- 
sion, but in this case it is difficult to deny the destructive force of Pope's lines. Their effect, once they are pointed out, is perhaps all the stronger for being unexpected, since the reader of 'The Progress of Poesy' is not normally sensitized to the Dunciad the way the reader of the Dunciad is to Virgil and Milton. It is curious that an unintentional allusion by a habitually unallusive poet should have provoked, in Wakefield and in the anonymous gentleman, the most explicit eighteenth-century statement of the effects of allusion that I know about.

How could Gray have blundered like this? One can only speculate, but the likeliest answer seems to me to be that he simply didn't think allusively. That is, once he had appropriated an image or a phrase the original context ceased to be important. He saw it only in the context of his own work; he treated it possessively; the act of appropriation made it his own. The results were seldom so catastrophic as those we have just seen, because Gray borrowed mostly from sources whose contexts did not clash violently with his own, and from such a wide variety of sources that potential clashes cancelled each other. Thus the final curious aspect of this powerful but unintentional allusion is the evidence it provides of Gray's habitual unallusiveness, for no poet who usually expected his own text to be actively compared to an earlier text could slip like this.

How then can we account for the great disparity between our notion of the practice of eighteenth-century writers and their almost complete silence about the nature and function of allusion? Given the case of Gray, we might argue that the use of allusion decreases markedly after the mid-century. It is certainly less prominent then, but far from absent: Cowper, for example, has a complex and very important allusive relationship to Milton, and Blake's 'London' alludes forcefully to Ezekiel. ${ }^{44}$ Another possibility is that allusion was so habitual a mode of writing and reading that critics felt little need to make its operations explicit, leaving it to act as an unexamined convention of discourse. This explanation would be more convincing if there were fewer eighteenth-century explanations of the obvious aspects of other topics. Warburton, for example, never shrinks from explaining features of Pope's verse that seem quite straightforward, yet he never tries to show exactly how his allusions operate.

I think a better explanation can be found in the way eighteenthcentury critics responded to imitation and its discontents. Even when justified, or indeed inevitable, as in writing on timeless and universal subjects like love, duty, and sunsets, imitation was seen as a necessary 
evil, the result of a fall from an earlier state of poetic grace and originality. Any similarity between two texts is potentially incriminating; the only real guarantee of innocence is difference. The assumption that imitators are doing the same thing as their models and cannot avoid competing with them intensifies the anxiety. Similarity and difference become antithetical. A mind-set like this makes it very difficult to accept allusive writing as a deliberate imitation of an earlier text for a significantly different purpose. Recognition of the similarities blinded readers to the differences, and vice-versa. Questions of property come in also. When successful imitation is seen as appropriation or assimilation, when a text asserts its own identity only by destroying the identity of an earlier text, it is hard to understand a technique in which the identity of a later text depends on maintaining the separate identity of an earlier text while at the same time asserting that the two texts are similar, sometimes almost identical. Eighteenth-century readers were thus prevented from understanding explicitly what I think writers like Dryden and Pope understood intuitively: the positive role that allusion can play in a fallen poetic world by enabling a poet to put to work, for his own purposes, the virtues and strengths of predecessors whom he cannot escape anyway.

To what extent, then, should these considerations modify our approach to eighteenth-century allusion? Do they justify Ehrenpreis's scepticism? Have the methods of reading that we have developed for Eliot and Joyce distorted our approach to Dryden and Pope? If we choose a historicist approach and seek eighteenth-century justification for allusive reading, I think there is enough evidence, scrappy and unsatisfactory as it is, to show that our interest in allusion is not entirely anachronistic. Their much greater preoccupation with imitation need not deter us from concentrating on allusion, unless we take the extreme position that our explicit critical categories should correspond exactly to those of the period we are studying. Understanding why they did not develop a more explicit rationale for allusion can help us relate our interests more clearly to theirs. The absence of allusion in Gray does not call into question its presence in Pope and Dryden; if anything, their allusiveness stands out all the more clearly by contrast.

Nevertheless, some cautions are in order. As I hope I have shown, not all writers are equally allusive. Not every imitation is an allusion. We have to guard against the temptation to inflate that afflicts all scholars: a 'source' is good only for a paragraph in Notes and Queries, but an 'allusion' is worth at least a substantial note and perhaps a whole article. Finally, we need to develop more precise and rigorous definitions of allusion, its functions, its capabilities, its limitations, and its relation to other poetic techniques. Here, instead of lamenting that our eighteenth-century 
forebears have disinherited us, we should perhaps rather rejoice that they have not pre-empted us.

\author{
WILLIAM KINSLEY \\ Université de Montréal
}

\title{
Notes
}

1 See Howard D. Weinbrot, Augustus Caesar in 'Augustan' England (Princeton, NJ: Princeton University Press, 1978) for an exhaustive account of the negative side of Augustus' image. Even a seemingly straightforward historical allusion like this one may have ambivalent meanings.

2 Ben-Porat, 'The Poetics of Literary Allusion,' PTL, 1 (1976), 105-28, and her Berkeley dissertation, 'The Poetics of Allusion' (1973); Perri, 'On Alluding,' Poetics, 7 (1978), 289-307.

3 For a thorough treatment of this aspect of Pope, see Maynard Mack, The Garden and the City: Retirement and Politics in the Later Poetry of Pope, 1731-1743

(Toronto: University of Toronto Press, 1969), esp. chapters 4-5.

4 An Essay Concerning Human Understanding, 2.11.2.

5 This aspect of allusion is illuminated by Maynard Mack in ' Wit and Poetry and Pope": Some Observations on his Imagery,' in Pope and his Contemporaries, ed. James L. Clifford and Louis A. Landa (Oxford: Clarendon Press, 1949), pp. 20-40.

6 An Essay on Man, 1.16. Pope's poetry is quoted from the Twickenham Edition of his Poems, gen. ed. John Butt (London: Methuen; New Haven: Yale, 1939-69), hereafter abbreviated as TE.

7 Miner, Dryden's Poetry (Bloomington: Indiana University Press, 1967); Brower, Alexander Pope: The Poetry of Allusion (Oxford: Clarendon Press, 1959); Ricks, 'Allusion: The Poet as Heir,' in Studies in the Eighteenth Century III, ed. R.F. Brissenden and J.C. Eade (Toronto: University of Toronto Press, 1976), pp. 209-40.

8 Among Rudat's many articles, see especially 'Allusive Technique in Pope's Early Rota Virgilii Poetry,' Antike und Abenland, 22 (1976), 70-99; 'Another Look at the Limits of Allusion,' Durham University Journal, 71 (1978), 27-34. For reactions to these and other articles, see the critiques in The Scriblerian. I agree that Rudat usually goes too far, but it is difficult to fix the limits of allusion unless someone with his combination of ingenuity and erudition risks going beyond them.

Wasserman, 'The Limits of Allusion in The Rape of the Lock,' JEGP, 65 (1966), 425-44. For a critique, see Ehrenpreis (note 10). See also reviews of Wasserman's Pope's 'Epistle to Bathurst': A Critical Reading with an Edition of the Manuscripts (Baltimore: Johns Hopkins University Press, 1960) by Robert M. Schmitz, PQ, 40 (1961), 418-20, and by Maynard Mack, MLN, 76 (1961), 872.

9 For one example, see Gérard Genette, Palimpsestes: La littérature au second degré (Paris: Seuil, 1982). Peter Hughes' stimulating attempt to go beyond conventional notions of allusion seems to me premature because we don't yet understand even 
the conventional notions well enough: 'Allusion and Expression in EighteenthCentury Literature,' in The Author in his Work: Essays on a Problem in Criticism, ed. Louis L. Martz and Aubrey Williams (New Haven, CT: Yale University Press, 1978), pp. 297-317.

10 Literary Meaning and Augustan Values (Charlottesville: University of Virginia Press, 1974), pp. 1-25. Ehrenpreis's more recent book, Acts of Implication: Suggestion and Covert Meaning in the Works of Dryden, Swift, Pope, and Austen (Berkeley: University of California Press, 1980) unfortunately discusses allusion only in passing, e.g. on pp. 88-89.

11 'Either' is a signal to look elsewhere, and I hope that some readers, at least those of my generation, caught the echo of Rudolf Flesch's once-famous book, Why Johnny Can't Read (New York: Harper \& Row, 1955). For what intention is worth, the allusion is meant to imply that 'illiteracy' is a perennial problem.

12 Poems, ed. James Kinsley (Oxford: Clarendon Press, 1958), 1, 48.

13 This was also one of Eliot's many motives for adding notes to The Waste Land: 'I had at first intended only to put down all the references for my quotations, with a view to spiking the guns of critics of my earlier poems who had accused me of plagiarism' (The Frontiers of Criticism,' On Poetry and Poets [London: Faber and Faber, 1957], p. 109).

$14 \mathrm{TE}, 5$, 3rd ed. (1963), 9. Cf. the more satirically convoluted dance of the same terms on pp. 52-53.

15 For a copious compilation of eighteenth-century dictionary definitions of 'allusion,' see Howard D. Weinbrot, 'The "Allusion to Horace": Rochester's Imitative Mode,' SP, 69 (1972), 350-52.

16 The Spectator, ed. Donald F. Bond (Oxford: Clarendon Press, 1965), 3, 578.

17 He uses this phrase in his Serious Reflections on Robinson. See Robert W. Ayers, 'Robinson Crusoe: "Allusive Allegorick History",' PMLA, 82 (1967), 399-407.

18 'A Dissertation on Poetical Imitation,' Works (1811), 2, 196-97. Hurd's italics.

19 'Essay the First, Concerning the Nature, Extent, and Reality of Human Knowledge,' Works (Philadelphia, 1841), 3, 131.

20 'Life of Cowley,' Rasselas, Poems, and Selected Prose, ed. Bertrand H. Bronson, 3rd ed. (San Francisco: Rinehart, 1971), p. 358.

21 Rambler 176, Works (New Haven, CT: Yale University Press, 1958 - ) , 5, 167.

22 The Minstrel, ed. Pierre Morère, Publications de l'Université des Langues et Lettres de Grenoble (1981), p. 94.

23 See Paul J. Korshin, Typologies in England 1650-1820 (Princeton, NJ: Princeton University Press, 1982), and Thomas R. Preston, 'From Typology to Literature: Hermeneutics and Historical Narrative in Eighteenth-Century England,' The Eighteenth Century: Theory and Interpretation, 23 (1982), 181-96.

24 4th ed. (1782; rpt. Farnborough, Hants.: Greg, 1969). Cited parenthetically in the text by volume and page.

25 In Studies in the Eighteenth Century IV, ed. R.F. Brissenden and J.C. Eade (Canberra: Australian National University Press, 1979), pp. 31-55. Lonsdale's subtitle alludes to Ricks's essay (see note 7), Oxford don saluting Cambridge don from 
far-off Australia, and in my subtitle a professeur de l'Université de Montréal salutes Oxbridge from Alberta.

26 See Harold Ogden White's thorough survey, Plagiarism and Imitation during the English Renaissance (Cambridge: Harvard University Press, 1935) and the more analytical study of G.W. Pigman III, 'Versions of Imitation in the Renaissance,' Renaissance Quarterly, 33 (1980), 1-32.

27 Pigman, pp. 4-7.

28 Pope, Prose Works 1711-1720, ed. Norman Ault (Oxford: Blackwell, 1936), pp. 90-91. One of Ault's reasons for attributing this essay to Pope is the resemblance of some of its images to those of the Preface of 1717, but Harold Williams calls the evidence for the attribution 'meagre' (RES, 13 [1937], 490).

Hurd finds a similar sort of pleasure in imitation, but he too fails to see any effect on the meaning of the later text: The pleasure we find in this exercise of the imagination ['to set two objects together, and contemplate their mutual aspects and appearances'] is the main source of that perpetual usage of indirect and allusive imagery in the writings of the poets' (Works, 2, 195).

29 The Art of Sinking in Poetry, ed. Edna Steeves (1952; rpt. New York: Russel and Russel, 1968, chap. 9, p. 39.

30 Prologue to Albumazar, 11-14; Poems, ed. Kinsley, 1, 141.

31 Letter of 2 July 1706; Correspondence, ed. George Sherburn (Oxford: Clarendon Press, 1956), 1, 19-20.

32 Lonsdale, p. 38; John Nichols, Literary Anecdotes of the Eighteenth Century (1812-15; rpt. New York: AMS and Kraus, 1966), 4, 429-37.

33 Works (1811), 2, 274. For a different view of 'allusion as agon,' see Robert Folkenflik, "Homo Alludens" in the Eighteenth Century,' Criticism, 24 (1982), 223-25. For earlier theories of emulation, see Pigman, 'Versions of Imitation.'

34 'Conjectures on Original Composition,' Complete Works, ed. James Nichols (1854; rpt. Hildesheim: Georg Olms, 1968), 2, 568-69. For a brilliant anatomizing of Young's essay, see Joel C. Weinsheimer, 'Conjectures on Unoriginal Composition,' The Eighteenth Century: Theory and Interpretation, 22 (1981), 58-73.

35 Nichols, Literary Anecdotes, 4, 429.

36 The Poems of Thomas Gray, William Collins, Oliver Goldsmith (London: Longmans, 1969).

37 'Gray and "Allusion",' p. 45.

38 Letter to Edward Bedingfield, 27 Aug. 1756; cited by Lonsdale, p. 45.

39 A Map of Misreading (New York: Oxford University Press, 1975), p. 125.

40 'Allusion and Melancholy in Gray's Ode on a Distant Prospect of Eton College,' Papers on Language $\mathcal{E}$ Literature, 15 (1979), 52-59.

41 Gray's line is even closer to the ending of the 1729 Dunciad, 'universal Darkness covers all.'

42 On these lines see also John E. Sitter, 'Mother, Memory, Muse and Poetry after Pope,' ELH, 44 (1977), 312-15.

43 Gentleman's Magazine, 51 (1781), 569; Lonsdale, Poems, p. 172. 
44 Dustin Griffin, 'Cowper, Milton, and the Recovery of Paradise,' Essays in Criticism, 31 (1981), 15-26; Harold Bloom, Poetry and Repression (New Haven, CT: Yale University Press, 1976), pp. 34-45. See also James K. Chandler, 'Romantic Allusiveness,' Critical Inquiry, 8 (1982), 461-87. 